\title{
Conventional Tracheotomy Versus Percutaneous Tracheotomy
}

\author{
Konvansiyonel Trakeotominin Perkütan Trakeotomi ile Karşılaştırılması \\ Erdinç AYDIN, Kübra AKMAN, Pelin KARAASLAN, ${ }^{1}$ Levent Naci ÖZLÜOĞLU \\ Departments of Otorhinolaryngology and 'Anesthesiology, Medical Faculty of Başkent University, Ankara
}

Submitted / Başvuru tarihi: 09.09.2008 Accepted/Kabul tarihi: 14.11.2008

\begin{abstract}
Objectives: Percutaneous tracheotomy is a relatively new technique which is considered as an alternative to conventional tracheotomy. While both techniques have their own advantages and disadvantages, the data related to long-term follow-up after percutaneous dilational tracheotomy (PDT) and its late complications are limited in the literature. The aim of this study is to compare both techniques according to the complications, patients' epidemiological situations, intubation duration, coagulopathy, mortality rates and cost-effectiveness.
\end{abstract}

Patients and Methods: We retrospectively evaluated 236 tracheotomy cases perfomed at our hospital between 1995-2007.

Results: There was statistically significant difference in complication rates between open and percutaneous tracheotomy techniques $(p=0.001)$. Major complications (TOF, tracheal stenosis, hemorrhage) were mostly related to PDT. However, stomal infection, stomal granulation tissue formation and cannula obstruction due to mucoid debris was more frequent in the open technique group. The mortality rate was found to be higher in the PDT group. Positive bacterial cultures on deep tracheal aspirations were significantly increasing the complication rates. Open technique costs were nearly twice that of percutaneous technique.

Conclusion: Major complications are more common with percutaneous tracheotomy compared to open technique tracheotomy according to our study results. Since in some cases PDT may necessarily be converted into an open technique; a surgically talented and equipped staff should perform this method.

Key words: Tracheotomy; percutaneous; dilational; complication.
Amaç: Perkütan trakeotomi görece olarak yeni bir teknik olup, konvansiyonel trakeotomiye alternatif olarak ortaya çıkmıştır. Her iki tekniğin avantaj ve dezavantajları olmakla beraber, literatürde perkütan dilatasyonel trakeotomi (PDT) ile ilgili uzun dönem takip sonuçları ve geç komplikasyonları ile ilgili bilgi sınırlıdır. Bu çalışma ile her iki tekniğin komplikasyonlar, hastaların epidemiyolojik özellikleri, trakeotomi endikasyonları, entübasyon süresi, koagülopatinin varlığı, mortalite oranları ve işlemlerin maliyeti açısından karşılaştırılması amaçlandı.

Hastalar ve Yöntemler: 1995-2007 yılları arasında hastanemizde gerçekleştirilmiş 236 trakeotomi olgusunun kayıtları retrospektif olarak değerlendirildi.

Bulgular: Açık ve perkütan trakeotomi komplikasyonları arasında istatistiksel olarak anlamlı fark saptandı ( $p=0.001$ ). Majör komplikasyonlar (TÖF, trakeal stenoz, hemoraji) sıklıkla PDT ile ilişkili bulundu. Bununla beraber stomal enfeksiyon, stomal granülasyon oluşumu, mukoid debris oluşumuna sekonder kanül obstrüksiyonu açık teknikte sık izlenmekte idi. Mortalite oranı PDT grubunda daha yüksek saptandı. Derin trakeal aspirasyon örneklerinde pozitif kültür varlığı komplikasyon hızlarını belirgin olarak artırmakta idi. Maliyet açısından değerlendirildiğinde açık tekniğin perkütan tekniğe kıyasla iki kat pahalı olduğu saptandı.

Sonuç: Çalışma sonuçlarımıza göre majör komplikasyonlar perkütan trakeotomi tekniğinde açık tekniğe kıyasla daha sık görülmektedir. Bazı olgularda PDT sonrası açık tekniğe dönmek gerekebilmektedir. Bu nedenle PDT, cerrahi olarak donanımlı ve ekipmanı yeterli bir ekip tarafından uygulanmalıdır.

Anahtar sözcükler: Trakeotomi; perkütan; dilatasyonel; komplikasyon.

Presented at the 29th Turkish National Otorhinolaryngology and Head \& Neck Surgery Congress, May 26-31, 2007, Antalya, Turkey (29. Ulusal Türk Otolarengoloji ve Baş Boyun Cerrahisi Kongresi'nde sunulmuştur, 26-31 Mayıs 2007, Antalya).

Correspondence (IIletişim adresi): Dr. Erdinç Aydın. Başkent Üniversitesi Tıp Fakültesi Kulak Burun Boğaz Hastalıkları Anabilim Dalı, 06810 Ankara. Tel: 0312 - 2238534 Fax (Faks): 0312 - 2239508 e-mail (e-posta): erdinca@baskent-ank.edu.tr

() Trakya Üniversitesi Tıp Fakültesi Dergisi. Ekin Tıbbi Yayıncıık tarafından basılımışır. Her hakkı sakııır.

(c) Medical Journal of Trakya University. Published by Ekin Medical Publishing. All rights reserved. 
Tracheotomy has been performed for nearly 3000 years. ${ }^{[1,2]}$ 'Tracheo-tomy' is a Greek compound name which means 'making an incision in the trachea' ${ }^{[2]}$ In the year 100 B.C., the Greek physician Asclepiades performed the first reported elective tracheotomy. ${ }^{[2]}$ In those years the technique was performed only in some infectious diseases like diphtheria and polio. But in the 20th century, Chevalier Jackson made the technique popular and it began to be applied in the intensive care units. ${ }^{[1,3]}$ The major indications for the procedure are upper airway obstruction, pulmonary aspiration and prolonged intubation. ${ }^{[3]}$ The common consensus is that, if the duration of intubation is more than 10 days and expected to be at least 21 days, tracheotomy should be performed. ${ }^{[1]}$ There are two techniques commonly used. During the open technique, a vertical or horizontal skin incision is made below the cricoid cartilage and by dissection tracheal cartilages are reached. ${ }^{[1]}$ In this method, the strap muscles are dissected, thyroid gland is mobilized to the superior or inferior region, the pretracheal fascia is passed through and cannula is inserted into the trachea from the second and third tracheal cartilage, after resecting a small piece of tracheal cartilage. In pediatric patients, the technique is different in which usually a vertical incision is preferred. Then the tracheal cartilage is elevated and fixed to the skin by traction sutures. ${ }^{[4-7]}$ Open technique tracheotomy may be conducted both in the operating room and on bedside. ${ }^{[3]}$

Percutaneous tracheotomy was first defined in 1969 by Toye and Weinstein. ${ }^{[5]}$ Then Ciaglia et al. modified the procedure and defined it as 'percutaneous dilational tracheotomy (PDT)'. ${ }^{[5-7]}$ This technique has been used frequently for the last 25 years and has been considered as an alternative to the conventional method. There are five different methods defined for PDT, but basically an angiocatheter is inserted below the cricoid cartilage percutaneously into the space between 2 nd and 3rd or 3rd and 4th tracheal rings. A guide is sent inside the catheter. Then a dilator is placed over the guide and enough stoma is achieved. The tracheal cannula is then inserted after replacing the dilator. Lately, this technique is being performed under endoscopic view..$^{[1,6-9]}$

In $5-40 \%$ cases, complications are seen in the postoperative follow-up. ${ }^{[2,10]}$ In a study, the mortality rate due to tracheotomy was determined as $2 \% .{ }^{[2]}$ The complications are classified into three groups as intraoperative, early postoperative, and late postoperative. ${ }^{[2,9]}$ Intraoperative complications are hemorrhage, air emboli, apnea and the injury to the peripheric tissue and organs. The early postoperative complications are hemorrhage, decannulationobstruction, subcutaneous amphysema, pneumothorax, peumomediastinum and infection. Late complications are hemorrhage, tracheal stenosis, tracheocutaneous fistula, tracheosophagial fistula (TOF). The most frequent complication is hemorrhage. ${ }^{[2,10]}$ Cannula obstruction, decannulation are the other frequently seen complica- tions. The incidences of pneumothorax, tracheal stenosis and TOF are less than $1 \% .^{[2]}$ The most commonly seen late complication is formation of grannulation tissue followed by tracheal stenosis. ${ }^{[11]}$ In emergency tracheotomy the complication rates increase two- to five-fold. ${ }^{[2]}$

The aim of this study is to compare both techniques according to the complications, patients' epidemiological situations, intubation duration, presence of coagulopathy, mortality rates and cost-effectiveness.

\section{PATIENTS AND METHODS}

Two hundred thirty-six patients who underwent tracheotomy between 1995 and 2007 were evaluated. Each patient's clinical data were retrospectively analyzed and their age, sex, body mass index (BMI), co-morbid diseases, tracheotomy indication, the duration of intubation, absence of coagulopathy, the place in which the procedure was performed (operating room versus bedside), deep tracheal infections, immunosuppression, use of antibiotherapy, complications of the technique, mortality rates and costs of the procedures were noted. Data from 19 patients were insufficient and a total of 217 patients were included in the study. Open technique tracheotomy was performed in 113 patients (group A), and PDT was performed in 104 patients (group B). In all but the first 10 PDT patients, endoscopy was used. Each group was compared according to age, sex, comorbid diseases intubation time, indication of the procedure, coagulation, coagulopathy, complications, mortality rates and cost. Also the relation between immunosuppression, deep tracheal infection, antibiotherapy, BMI, place of the operation (operating room versus bedside), organ transplantation, burn injury and complications were investigated. Intubation time was recorded in days. The tracheotomy indications were grouped as, prolonged intubation, upper airway restriction, frequent airway toilet. Coagulation disorders due to anticoagulant therapy was marked as none, clexane ${ }^{\circledR}$, fraxiparine ${ }^{\circledR}$, heparin, coraspin $\AA$, coumadin $\AA$. Immunosuppression, deep tracheal infection and antibiotherapy were mentioned as positive or negative. Place of the procedure was basically categorized as bed-side or in the operating room. Organ transplant patients were grouped as renal or liver. Burn injury was noted as positive or negative. The complications were categorized in eight sub-groups as; no complication occurred, hemorrhage, stenosis, fistula, decannulation, obstruction, subcutaneous amphysema and others (stomal infection, stomal granulation).

All statistical analyses were performed using SPSS for Windows Version 11 (SPSS, Inc. Chicago, IL). A value of $p<0.05$ was accepted as statistically significant. The analyses of two continous variables were performed by independent samples t-test where parametric assumptions were provided, if not Mann-Whitney U-test was performed. The analyses of three or more continuous variables were performed by Kruskal-Wallis test where 
Table 1. Sex distribution in both tracheotomy groups

\begin{tabular}{lccc}
\hline & Group A & Group B & Total \\
\hline Female & 40 & 45 & 85 \\
Male & 72 & 60 & 132 \\
\hline
\end{tabular}

parametric assumptions were not provided. Chi-square test was performed for analyses of qualitative variables.

\section{RESULTS}

The median age was 65 years (range 0 to 97 years). The mean ages in group A and group B were $49.7 \pm 2.8$ and $65 \pm 1.7$ respectively. The difference in ages were statistically significant $(p=0.001)$. There were 85 female, 132 male patients (Table 1). No statistically significant difference was noted according to sex in each group ( $p>0.05)$. 143 patients were given anticoagulant therapy, of which 83 were given clexane. Eight of them were given heparin. Five patients were using coraspin and seven patients were coumadinized. Thirty patients were having combined anticoagulant drugs. Seventy-one patients had no coagulaopathic disorder. The mean intubation duration in group 1 was $15.27 \pm 1.4$ days. In group 2 it was $13.55 \pm 1.5$ days. This was not significant in both groups $(\mathrm{p}>0.05)$. Total number of patients who survived was 73 , and 141 patients died. The mortality in group A was $45.4 \%$, while it was $54.6 \%$ in group B. The results were significant $(\mathrm{p}<0.05)$ (Table 2$) .85 .1 \%$ of group A had no complications but in group B only $14.9 \%$ of cases were free of complications. The difference in complication rates were statistically significant $(p=0.001)$. The complication sub-groups were separately evaluated. According to this, 12 patients had hemorrhage and 10 of them were in group B. Stenosis was seen in four patients and one of them was in group A. In six patients TOF was seen and five of them were in group B. Three patients from each group had decannulation problem. Cannula obstruction was observed in four group A patients and one group B patient. Subcutaneous amphysema was seen in two patients in group A but in group B, it was seen only

Table 3. Comparison of complications in open versus percutaneous dilational tracheotomy techniques

\begin{tabular}{lcccc}
\hline Complications & $\begin{array}{c}\text { Group A } \\
\text { (Open) }\end{array}$ & $\begin{array}{c}\text { Group B } \\
\text { (Percutaneous) }\end{array}$ & Total & $p^{*}$ \\
\hline Hemorrhage & 2 & 10 & 12 & \\
Tracheal stenosis & 1 & 3 & 4 & \\
TOF & 1 & 5 & 6 & \\
Decannulation & 3 & 3 & 6 & 0.001 \\
Cannula obstruction & 4 & 1 & 5 & \\
$\begin{array}{l}\text { Subcutaneous } \\
\text { amphysema }\end{array}$ & 2 & 1 & 3 & \\
$\begin{array}{l}\text { Granulation } \\
\text { and stomal infection }\end{array}$ & 4 & 0 & 4 & \\
\hline
\end{tabular}

${ }^{*}$ Chi-square test.
Table 2. Comparison of both tracheotomy techniques

\begin{tabular}{lccc}
\hline & Group A (n=112) & Group B (n=105) & $p$ \\
\hline Mean age & $49.71 \pm 2.8$ & $65.02 \pm 1.7$ & $0.001^{*}$ \\
Mean intubation & $15.27 \pm 1.4$ & $13.55 \pm 1.5$ & $\mathrm{NS}^{* *}$ \\
duration (day) & & & \\
Mortality rate & $45.4 \%$ & $54.6 \%$ & $0.001^{* * *}$ \\
$\begin{array}{l}\text { Culture positivity } \\
\text { in deep tracheal aspirate }\end{array}$ & $68.2 \%$ & $0.001^{* * *}$ \\
\hline
\end{tabular}

NS: Non-significant; *Mann-Whitney U-test; **Independent samples t-test; ${ }^{* * *}$ Chi-square test.

in one patient. Stomal infection and granulation were frequent in group A, compared to group B (Table 3). We also compared the relation between immunosuppression, organ transplantation, burn injury, BMI, antibiotherapy, deep tracheal infection, coagulation, intubation duration, place in which the procedure was performed, and the complication rates. According to this, there was no significant correlation between immunosuppression and complication rates. $75 \%$ of immunocompromised patients had no complications, whereas this ratio was $69.3 \%$ in the non-immunocompromised group ( $p>0.05)$. Moreover, organ transplantation and burn injury were not predisposing factors for the complications ( $p>0.05)$. There was no statistically significant BMI difference between two groups ( $p>0.05)$. Antibiotherapy was not effective on the complication rates $(p>0.05)$. There was a significant relation between deep tracheal aspirate infection and complication rates. Especially, stomal infection and granulation were closely related with deep tracheal infection $(p<0.05) .91 .2 \%$ of patients who did not have deep tracheal infection had no complications but only $64.4 \%$ of patients with deep tracheal infection were free of complication. No difference was observed between coagulopathies and complication rates which indicates that any anticoagulant agents in our study do not directly influence the complications developed ( $p>0.05)$. We also checked whether there was a significant difference between the intubation indications and complication rates but no difference was observed $(p>0.05)$. The room in which tracheotomy was performed significantly affected the complication rates. According to this result, $81 \%$ of patients with no complications were operated in the operating room $(p=0.001)$. Most of the open technique tracheotomies in this study were performed in the operating room.

The expenditure of both techniques were evaluated and for our hospital, it was calculated that open technique cost 532 euros, while percutaneous technique cost 208 euros.

\section{DISCUSSION}

Percutaneous tracheotomy began to be frequently performed in the last years and this technique is considered as an alternative to conventional method. In the litera- 
ture, there are studies supporting PDT as a cost-effective method, which has low complication rates compared to the open technique. It is also mentioned that performing this technique takes less time.

In 1991, Hazard et al. showed in their prospective randomized study that the complication rate of percutaneous tracheotomy was $25 \%$, while in the same study the rate of open technique was 58\%. Also in 1995, another study by Freidman et al. showed 12\% and 41\% complication rates in percutaneous tracheotomy and open technique, respectively. Freidman mentioned that this new technique is applied in a short period and has less morbidity. In another prospective randomized study performed in 1999, the minor complication rates were found similar in both techniques. According to Morelli et al. after using endoscopy during the procedure, percutaneous tracheotomy has started to become less complicated. We also found that PDT was less complicated when applied endoscopically. In the first ten cases in whom PDT was performed, the complication rates were higher. TOF was seen in two cases and cricoid cartilage fracture was seen in one endoscopy-free PDT. The general consensus is not to perform PDT in pediatric, morbid obese and coagulopathic patients ${ }^{[12]}$ However, there are studies approving PDT in pediatric and morbid obese patients, only if peroperative multidisciplinary approach and endoscopic examination is possible. ${ }^{[6,7]} \mathrm{In}$ our study, no increased complication rates were found in coagulopathic patients treated by PDT. Hutchinson and Mitchell mentioned that by using 'Rapitrec' in PDT, two patients had tension pneoumothorax and one of them had died. They emphasized that in all their PDT cases, pseudotract occured. Wang et al. ceased their study due to complications like pneumothorax, decannulation and death seen in three patients after PDT. They defined the technique as a dangerous procedure which has major complications and contribute to death'. In their study, van Heurn et al. ${ }^{[8]}$ examined trachea histopathologically after PDT. They found that in patients who stayed tracheotomized for more than 10 days, there were one or more stenotic locus in the trachea. ${ }^{[13]}$ Moreover, 11 patients had cricoid cartilage fracture and deep mucosal ulceration, eight patients had one or more tracheal ring injury, three patients had cricoid cartilage injury and in two patients protrusion of the tracheal wall through the lumen occurred ${ }^{[8]}$ In a meta-analysis, 7697 open technique tracheotomy and 1817 PDT cases were compared. Peroperative complications and mortality rates were found higher in PDT. ${ }^{[13]}$ Higgins and Puntakhee ${ }^{[3]}$ compared both techniques. Their meta-analysis showed that decannulation and obstruction were seen more in PDT. Conversely, cannula obstruction rate was found lower in PDT group in our study. This may be because most of the PDT group patients were treated in the intensive care units. So any sudden changes in the vital functions were observed and treated in seconds. On the other hand, wound infection and stomatitis were more frequent in open technique. ${ }^{[13]}$ Similar results were observed in our study. Subcutaneous amphysema was seen in two patients in group A. Whereas there was only one group B patient with this complication. This is an expected result since during the open technique tissue plans are dissected and become vulnerable to amphysema.

Some authors say that PDT is cheaper and takes less time to perform. But bedside tracheotomy choice is still advised to be the open technique. ${ }^{[3]}$ Percutaneous dilational tracheotomy seems to have the advantage of being applied by non-surgeon health givers. In fact, there are so many studies suggesting that this technique has better results, if performed by surgeons. ${ }^{[3]}$ In our study, open technique tracheotomy was applied by surgeons and PDT was applied by anesthesiologists.

In cases in which the anatomical neck landmarks are difficult to palpate, use of open technique is suggested. If necessary, PDT should be applied endoscopically. According to Massick et al. ${ }^{[16]}$ there are two circumstances that PDT were contraindicated. If the procedure is planned on bedside, surgical equipment and trained team should be available. If not, PDT is contraindicated. Our study results also support their findings. In two patients who underwent percutaneous tracheotomy, the procedure failed and open technique tracheotomy had to be applied. The complication rates were less in patients who underwent tracheotomy in the operating room. In the operating room, patients' anesthetic medications are easily applied, surgeon is more comfortable in giving the best position to the patient. The lightening is optimal. All the surgical equipment is available. Patients' vital functions are well monitored. In this study, most of the patients in group B were operated in the intensive care unit (bedside). Furthermore, patients who have suboptimal cervical anatomy PDT is strictly contraindicated. ${ }^{[14-16]}$ Our findings showed that there is no significant relation between BMI and tracheotomy complications. Further investigations which include cervical thickness measures may be appropriate. In a study which was published in 2005, Epstein mentioned that suprastomal stenosis is frequently seen after PDT, due to posterior tracheal wall injury. ${ }^{[10]}$ Another study showed that in 19 PDT with Grigg's Technique (clamp dilation) 12 patients had more than $10 \%$, two patients had more than $25 \%$ stenosis of the tracheal lumen. In all cases, PDT was performed endoscopically. ${ }^{[1]}$

It should be kept in mind that complications related to open technique tracheotomy decrease as time passes. To our knowledge, the long-term follow-up results of both procedures and the long-term complication data are limited in the literature. This study lightens further investigations. However, this study shows that open technique tracheotomy is more convenient compared to percutaneous tracheotomy. But it should also be considered that our patient spectrum had many co-morbid diseases especially in group B. This may also contribute 
to high complication and mortality rates within this group. The major systemic problems were cardiac, neurologic, endocrinologic, surgical and related to renal and liver insufficiency. Since there were so many comorbid diseases, statistical analyses regarding the relation of diseases with complications could not be performed. Further investigations may be undertaken. The mortality was found higher in group B. This result may not be directly related with the procedure itself. Group B patients' mean age was found to be higher and they had other systemic diseases. They were treated and followed in the intensive care units. These factors affect survival negatively. Another result found in our study is that there was a significant difference in mean ages of both groups. To our knowledge, there was no data in the literature emphasizing this kind of difference. In our hospital, PDT is usually performed in intensive care units. That is why the patient spectrum is elderly compared to the open technique patients.

In conclusion, our study revealed that there was statistically significant difference in complication rates between open and percutaneous tracheotomy techniques. Major complications (TOF, tracheal stenosis, hemorrhage) were mostly related to PDT. However, stomal infection, stomal granulation tissue formation, and cannula obstruction due to mucoid debris was more frequent in the open technique group. The mortality rate was found to be higher in the PDT group, but considering the higher mean age and prevalence of comorbid diseases in this group, higher mortality was not unexpected.

\section{Acknowledgement}

We are grateful to Işıl İrem Budakoğlu, MD, Assistant Professor from Gazi University Medical Faculty for performing the statistical analysis of the manuscript.

\section{REFERENCES}

1. McWhorter AJ. Tracheotomy: timing and techniques. Curr Opin Otolaryngol Head Neck Surg 2003;11:473-9.

2. Goldenberg D, Ari EG, Golz A, Danino J, Netzer A,
Joachims HZ. Tracheotomy complications: a retrospective study of 1130 cases. Otolaryngol Head Neck Surg 2000;123:495-500.

3. Higgins KM, Punthakee X. Meta-analysis comparison of open versus percutaneous tracheostomy. Laryngoscope 2007;117:447-54.

4. Carron JD, Derkay CS, Strope GL, Nosonchuk JE, Darrow $\mathrm{DH}$. Pediatric tracheotomies: changing indications and outcomes. Laryngoscope 2000;110:1099-104.

5. Bartels S, Mayberry JC, Goldman RK, Askew JA, Wax MK. Tracheal stenosis after percutaneous dilational tracheotomy. Otolaryngol Head Neck Surg 2002;126:58-62.

6. Blankenship DR, Kulbersh BD, Gourin CG, Blanchard AR, Terris DJ. High-risk tracheostomy: exploring the limits of the percutaneous tracheostomy. Laryngoscope 2005;115:987-9.

7. Baek CH, Chung YJ, Jeong HS, Kim SW. Comparison of open dilatational tracheostomy with conventional pediatric tracheostomy in a growing animal model. Laryngoscope 2005;115:2193-8.

8. van Heurn LW, Theunissen PH, Ramsay G, Brink PR. Pathologic changes of the trachea after percutaneous dilatational tracheotomy. Chest 1996;109:1466-9.

9. Donaldson DR, Emami AJ, Wax MK. Endoscopically monitored percutaneous dilational tracheotomy in a residency program. Laryngoscope 2000;110:1142-6.

10. Taş A, Yağız R, Topçuoğlu T, Koçyiğit M, Uzun C, Karasalihoğlu AR. Uzamış entübasyonlu hastalarda trakeotomi sonuçları. Trakya Univ Tip Fak Derg 2008;25:34-7.

11. Epstein SK. Late complications of tracheostomy. Respir Care 2005;50:542-9.

12. Pirat A, Zeyneloglu P, Candan S, Akkuzu B, Arslan G. Percutaneous dilational tracheotomy in solid-organ transplant recipients. Transplant Proc 2004;36:221-3.

13. Bikhazi NB. Percutaneous tracheotomy: has its time arrived? Arch Otolaryngol Head Neck Surg 2001;127:221-3.

14. Fazekas-May MA. Percutaneous tracheotomy: is it time to reconsider our approach? Arch Otolaryngol Head Neck Surg 2001;127:223-4.

15. Donovan DT. Percutaneous tracheotomy may be useful in both surgical and intensive care settings, but is no replacement for the open procedure. Arch Otolaryngol Head Neck Surg 2001;127:225-6.

16. Massick DD, Powell DM, Price PD, Chang SL, Squires G, Forrest LA, et al. Quantification of the learning curve for percutaneous dilatational tracheotomy. Laryngoscope 2000;110:222-8. 